International Journal of English Literature and Social Sciences
Vol-6, Issue-2; Mar-Apr, 2021

\title{
John Keats's Odes: A Balm to a Tired some Soul: With Reference to Ode to Psyche, Ode on a Grecian Urn, Ode on Melancholy and Ode to Autumn
}

\author{
Hari Shankar Mukherjee
}

Master in English (Pursuing), Department of English and Culture Studies, The University of BURDWAN, West Bengal, India.

Received: 12 Nov 2020; Received in revised form: 02Feb 2021; Accepted: 19 Feb 2021; Available online: 05 Mar 2021

(C)2021 The Author(s). Published by Infogain Publication. This is an open access article under the CC BY license

(https://creativecommons.org/licenses/by/4.0/).

\begin{abstract}
The odes show a journey towards the meaning of existence through actual human experience as well as the intense experience to be found in art. In his letter to Reynolds, Keats clearly stated his purpose by comparing life to "a large Manson of many apartments" in which he describes his journey from the infant or thoughtless chamber to dark passages through the delightful chamber of the maiden thought.In these poems, we find a dialogue between transience and eternity,climaxing not in the beauty- truth equation but the mood of acceptance.From the romantic anguish, he moves on to what Arnold said the ability to see life in its wholeness which is so characteristic of Hellenism.
\end{abstract}

Keywords-existence, eternity,transience, wholeness, Hellenism.

\section{INTRODUCTION}

Keats, like Horace of the antiquity and Shakespeare among the Elizabethans,was deeply concerned with the problem of beauty and mutability. In his great odes, Horace treats the theme with considerable variations. Shakespeare in his sonnets shows an unusual awareness about the beauteous forms and the transience.The most passionate appreciation of beauty is qualified by a painful awareness that "Everything that grows/Hold imperfection but a little moment." The poet knows that before the 'devouring time'that 'blunt' the 'lion's paws' beauty is too tender to hold its plea.Keats,as we know,wanted to "approximate" the English poets" by which he meant mainly Spenser,Shakespeare, and Milton.Keats took human life as an adventure, a journey through the dark chambers in search of truth and beauty, [ his letter to Reynolds.] As he was navigating along the shores of darkness he was progressing very fast towards maturity, perfection, and the tragic vision which he found in Shakespeare.His odes in various keys try to present the theme with a sensibility unmatched by any poet save Shakespeare.

\section{DISCUSSION}

Ode To Psyche in a way is rendering of Keats`s meditations on the introspective nature of philosophy and art. It should be noted that Keats suggests the evolution of the human mind towards self-knowledge and the quest for beauty through the exploration of the Greek myth. Ode To Psyche standing for the mind,as well as for the beauty is after all the least form of Olympian hierarchy lacking in all the ceremonial rights and rituals, has no temple," Nor altar heap'd with flowers;/ Nor virgin -choir to make delicious moan/Upon the midnight hours." She has " No shrine, no grove,no oracle...', yet she is the brightest with the brightness that the seeing power of the mind can lend.The poet promises to build all the holiness and the mystic with the meditation of imagination. He would be her priest,build for her temple surrounded by branched thoughts in some solitary region of his mind," with the wreath'd trellis of a working brain." He would create all the wonders - "buds, and bells,and stars without a name." Poetry has the power to create such an image of beauty even though the old religions have faded.Keats thus is all for creating a new secular religion of aesthetic to replace the old and theocentric,mythological religions which cannot stand the scrutiny of emergent reason. 
The Ode on a Grecian urn, for Keats,symbolized the world of ancient Greeks who achieved a perfect balance between form and beauty. The poem begins with an apostrophe," Thou still unravish'd bride of quietness." And "foster-child of Silence and slow Time," but it is also a "Sylvan historian" which can express "a flowery tale more sweetly than our rhyme". It is followed by a repeated question regarding the place or the theme or characters depicted so eloquently on the urn. The piper on the urn goes on playing his unheard melodies, the lovers are frozen in a jester of dalliance unable to consummate the love and the religious procession headed by the mysterious priest on a pious morn against the background of a desolate city by the sea will remain an enigma.The urn,remaining outside the flux of time has acquired a timeless quality denied to human beings. Our passions, that is, consuming and "leaves a heart high -sorrowful and cloy'd." Art,however, is free from all the sense of sadness or languor.Like eternity,it also "tease us out of thought." Human life is mutable,generations fall into decay and die but the "Cold Pastoral" with the vibrant carnival of life exists in its eloquent isolation.

The urn is a friend to a man who is not a subject to time's inexorable course decay and death.It should be noted that Keats has by this time established the urn not only as a relic of the old age and a dead civilization but a philosopher- historian dramatizing the external things of life in forms and lives. The question that goes on teasing us, Is the world of beauty,however,deeply moving and ageless, can give us a perception of truth?Plato in his dialogues answered with an unambiguous no. His argument was that the phenomenon of reality is only a copy of the timeless "Idea" and a work of art is merely a copy of a copy,it is deceptive and based on falsehood. The platonic argument has continued too long in the discourse of art creating an artificial schism between beauty and truth. No such distinction exists for Keats who finds them united in a superior order of reality.Man's perception of reality need not be incomplete nor are beauty and truth mutually exclusive. They can be unified to create a fuller life in which intense enjoyment of beauty exists in perfect harmony with the intuitive and luminous realization of truth.Keats's synthesis would later become a romantic credo popularized by the French poet-critic, Theophile Gautier who spoke of an aesthetic trinity - the truth, the good, and beauty - to be rendered in Sanskrit by Jyotindranath Tagore as "Satyam,Shivam,Sundaram."

As we know Ode On Melancholy was prompted by Keats's reading of Burton's Anatomy of Melancholy in which the seventeenth-century writer dealt with various forms of what today is known as depression and various abnormal states of mind. Originally the poem opened with a stanza containing the picture of a specter ship which was later rejected and Keats also considerably changed the text. These changes were necessitated by Keats's changed perception of the nature of melancholy: from pathology, he was moving to philosophy that would encompass the whole of human existence showing its relation to reality. He,unlike, Burton does not associate melancholy and depressing things - 'wolf's - bane, nightshade' or the weeping 'yew - berries' that are associated with the gloom of the grave-yard. The poem opens dramatically in which the poet exhorts the reader to give the easy routes of escape through suicide or indulging into depression, in the darkest shades of the mind represented by the 'downy owl.' Instead, Keats suggests a tragic alternative of the tragic aspects of reality by "the wakeful anguish of the soul." The mind transcends pain only when it experiences it consciously with a receptive mind.

The proposition in the first stanza is amplified in the second in which he provides a virtual feast for the senses and indulgence into the beauties that the world can offer.The world of the process unfolds a life - death pattern that perpetually replenishes and renews itself.The April rains that nourish and preserve the droop-headedflowers also cover the green hill like a shroud.Death is hidden in growth and decay threatens beauty - whether the iridescent hues of the rainbow after a wash or the beauty of morning rose and the wealth of 'globed peonies.' The evanescence of beauty can be experienced by imprisoning the soft hands of one's beloved letting her show rich anger and feed 'deep, deep upon her peerless eyes.' This only leads one to the paradox that the intense enjoyment of beauty must necessarily invite its opposite, the depth of pain. The solemn image of melancholy is to be found 'in the very temple of Delight.' The image of 'Delight' is like a veil of a mask that must be penetrated to grasp the truth behind it. Melancholy is thus the supreme permanent reality ( sovereign) and she is also the unmoved mover lending dynamism to life's endless cycle running through birth,decay, and death.

Ode To Autumn considered to be Keats's swan song is also one of acceptance.The ode also brings out in full Keats's mythopoetic imagination and the painfully acquired mastery over the form.Autumn presents a picture of plenty, fruition, and ripeness indicated through such verbs and adjectives as 'load', 'round', 'swell', 'plump', 'sweet', 'o'er -brimm'd'. Yet this picture of plentitude worked out with the magic of sensuous detail also foreshadows the great emptiness and sadness of Autumn presaging, as it were the death-like silence and frigidity of winter.The anguished voice asks, "where are the songs of Spring?" The poet realizes that the vibrant sonority of the spring has been replaced by the threnody of Autumn. 
Keats comes closer to Shakespeare's tragic optimism expressed in King Lear, "ripeness is all" .He also realizes that Autumn has a place in the scheme of things and we must have the courage to accept life in its totality; with all its intellectual process of decay and death; involving as it must, emptiness,despair, and gloom.

\section{CONCLUSION}

The Odes,therefore,register the steady growth of the poet's mind through the labyrinths of despair, an anguished realization of the dichotomies of human existence to a mature vision of life and art. Keats travels right into the dark corridors of life, always trying to grapple with reality and almost always succeeding in rendering the tension, passionate questionings, and convictions with adequate images that are both sensuous and cognitive, all pointing out to ever-widening vistas of thought and feelings.

\section{REFERENCES}

[1] Weeks A.R, The Odes of John Keats. Published by BooksWay,ISBN 978-93-80145-56-3,Second Reprint 2015

[2] Hough Graham, The Romantic Poets.

[3] Sengupta Subodh Chandra, Keats: From Theory to Poetry,First Published November 1986by Shishu Sahitya Samsad Private Ltd.

[4] Gittings Robert, John Keats: Selected Letters, Oxford World Classics:2009

[5] Chatterjee Bhabatosh, John Keats: His Mind and Work, Sarat Book Distributor, ISBN 81-87169-05-2, Reprint January 2001

[6] Twentieth Century Interpretations of Keats's Odes: A Collection of Critical Essays, edited by Jack Stillinger.Englewood Cliffs, NJ: Prentice-Hall:1968s 